\title{
The Call of the Wild: John Buchan's Heroes and the Decline of British Aristocracy
}

\author{
PILVI RAJAMÄE
}

\begin{abstract}
The article will look at how John Buchan (1875-1940) has traced the decline of British aristocracy in his novels that cover the time period when the power radically shifted from the landowning to the middle class, with concomitant feelings of confusion, loss, disillusionment and inadequacy on the part of the class whose very existence was being undermined. Buchan wrote at the time when the spirit of chivalry, so carefully cultivated by the Victorian chivalric revival, still coloured the thinking of the aristocracy and the upper middle class, soon to be extinguished by the trenches of the Great War. This spirit abhorred middle-class mercantilism and pragmatism. Thus we see Buchan's aristocratic heroes, beleaguered by the encroaching spirit of worldliness, going questing in the wilderness to regain their mental balance and purpose. Romantically communing with nature and following their ideals, they fulfil their personal quests, thus reasserting the concepts of duty and selfless service that had been part of the aristocratic code of honour before it was made redundant by middle-class materialism.
\end{abstract}

Keywords: John Buchan; Scottish literature; decline of the British aristocracy; Victorian chivalric revival

John Buchan (1875-1940) was a prolific Scottish writer of spy fiction, historical novels, short stories and biographies. He also developed a parallel career as a publisher and politician, representing the Scottish Universities in the British parliament and ending his career as Governor-General of Canada. Himself of a lower middle-class origin, through sheer determination and hard work he educated himself by winning scholarships first to Glasgow University and then Oxford University. His rise in status was confirmed when he married into the influential aristocratic family the Grosvenors and cultivated friendships with the high and mighty, including two Prime Ministers, Stanley Baldwin and Ramsay MacDonald. His life-span witnessed the steady erosion of power and decline in status of the British aristocracy, as throughout the nineteenth century the middle class, men of finance and industry, were undermining the very base of the arsitocrats' essentially agrarian existence. In his fiction 
Buchan has chronicled this decline with the poignant sympathy of a man who sees the beau ideal to which he has aspired and in which he delights crumbling before his very eyes. The plight of the aristocracy was intensified by their lack of comprehension as to its exact cause. Circumstances that appear clear and inevitable to us in retrospect appeared muddled and confused to those who went through these changes, as amply demonstrated by David Cannadine in his magisterial The Decline and Fall of British Aristocracy (1990) which the present article will frequently refer to. The aristocracy's plight was further compounded by the rampant spirit of mercantilism, the driving engine of Victorian reform. The aristocratic code of honour could rarely compete with materialism and money-making.

My central argument in the present article would be that Buchan's response to these events reflected and was conditioned by the ideals of the class to which he mentally and spiritually aspired - the aristocracy - whose reaction to unfolding social and cultural changes tended to be uncomprehending and defiant, being steeped in their own self-mythologizing and class prejudice. The resultant fiction, both historical and treating the modern condition, reflects this moral confusion both in its content and form. The ideals Buchan's heroes pursue tend to be elusive and the resultant framework for their search shaky through no fault of their own or their creator. The environment they operate in is constantly shifting, as old certainties are eroded and new ones refuse to evolve. Buchan's fiction throughout his long literary career can be viewed as an attempt to grapple with this accelerating uncertainty. Taking no delight in the iconoclasm of the avant-garde, his is a search for certainty in the middle of chaos the conditions of which are set by the death throes of his chosen class. In different disguises the same pattern is manifest through his books, even when they ostensibly deal with other climes and nations. Strikingly, but not really surprisingly, there is a steady pattern of defeat and withdrawal and the agent of evil is always the same - mercantilism. Romantically, as befits the spirit of the times, the heroes opt to retreat to wild nature to come to terms with the crisis. For some lucky ones there are spiritual rewards and an affirmation of their correct choice in the end, others just perish nobly, their sacrifice unsung and unknown.

We find this pattern already in place in Buchan's very first book Sir Quixote of the Moors (1895). Resounding with echoes of Tennyson's Idylls of the King, it traces the love triangle of Arthur/Lancelot/Guinevere in Covenanting Scotland. In the Idylls, Guinevere as Sense and Arthur as Soul enact the evangelical Victorian battle with worldliness, Arthur's chastity vanquishing Guinevere's sensuality. Following in their footsteps, Sieur de Rohaine, the 
RAJAMÄE

quixotic protagonist of Buchan's novel, fights his own fervent battle with encroaching worldliness in the person of a minister's daughter whose unwitting sexual allure poses a threat to his chastity when she falls in love with him, neglecting her Convenanting lover. However, at the critical moment, on the very brink of surrendering to the emasculating joys of domesticity she seems to be holding out to him, he, like Arthur, chooses sexual purity and, like Lancelot escaping from his passion for Guinevere, opts for manly questing in the wilderness.

Several things strike the eye. Sieur Rohaine is an aristocrat who has lost his bearings, both literally and figuratively. His identity is in shambles, having been eroded by rampant mercantilism and loose living which follows from it. He is in need of regeneration which he achieves by undergoing a spiritual trial in the wilderness of Galloway moors. He cannot hope for sympathy or understanding of his predicament as the people who have caused it are unable to rise to his level of spiritual refinement, neither do they share his ideals.

A similar pattern can be observed in A Lost Lady of Old Years (1899). Here a dissolute aristocrat whose noble nature has been compromised by illegitimate birth and the taint of middle-class blood finds regeneration through a journey to the wilderness of the Scottish Highlands and tying himself to the lost cause of Bonnie Prince Charlie. He, too, is tempted by happy domesticity but turns his back on it, preferring a solitary quest of honour in provincial obscurity.

These are historical romances, set in environments that are provincial and emulative, deeply indebted to Scott and Stevenson, as is John Burnet of Barns (1898) in which the eponymous protagonist's forced wanderings in wilderness also contribute to his self-analysis, though he succumbs to domesticity in the end. Yet, the deliberate, self-imposed obscurity of a provincial squire is here present too.

After going to Oxford Buchan chose to stretch his wings and embark on a Condition of England novel. The result - The Half-Hearted (1900) - places the author and his hero into the midst of the chaos which is modernity and subjects the earlier, safe and borrowed presumptions to critical scrutiny. The book is shaky and uneven, as Buchan is stumbling on unfamiliar ground, but the general unease so manifest in the book can also be attributed to the confused nature of the topic Buchan has chosen to explore. The concerns he had dealt with at one remove, in safe historical environments, have now to be tackled directly.

The novel's protagonist Lewis Haystoun is a scion of an ancient and venerable Scottish lineage, the last of his line, and his problem is the supposed half-heartedness of the title. In fact Lewis is nothing of the sort but his peculiar 
predicament highlights the impasse reached by his whole class. The book is so faithful in rendering the troubled confusion of the aristocrats of the time that it can serve as a virtual handbook of their problems when dealing with the increasingly predominant middle classes. The book deserves closer inspection as it prefigures Buchan's later variations on the topic in other periods and countries.

Haystoun is the perfect embodiment of all chivalric virtues honed to perfection by the Victorian chivalric revival. These virtues are shown to clash most painfully with middle class suburbanism embodied by his loved one Alice and his rival Mr Stocks. The overpowering personality of the latter and his single-minded mercantilism (so evocatively foregrounded by his name) serve to highlight Haystoun's weakening position as an aristocrat. The chivalric code of honour that has sustained his class through centuries of aristocratic rule is shown to be inadequate under the new conditions of middle-class ascendancy. Both in public and private life the rules are changing and the aristocrats have difficulty catching up.

The traders built but the aristocrats administered the Empire. The latter, always a travelling class, saw themselves as pioneers and explorers, carrying the British flag to distant corners of the earth. The more beleaguered by the middle class they felt at home the more passionate grew their travels. As the book opens, Haystoun has just returned from a four-year trip to the more inaccessible parts of Kashmir, a thinly disguised tour of reconnaissance of the North-West Frontier where the Great Game of imperial hide-and-seek with Russia was being played out. This establishes Haystoun as a man with global interests and grasp, to be thrown starkly against the narrow provincialism of Mr Stocks. The martial virtues of the warrior class that sustain the Empire are shown meeting the stone wall of incomprehension on the part of domesticated suburbanites whose narrow horizons prevent them from rising above the limited concerns of their class.

The novel is particularly good in reflecting the then current concerns with imperial sustainability and the concomitant fear of suburban domesticity as contributing to imperial slackness. The moment Haystoun arrives home, he receives a dire warning from his local doctor about the dangers of slackness and settling down. The Carlylean injunction to find one's calling and doing one's duty to fulfil one's higher destiny, here expounded fully as nowhere else in Buchan's oeuvre but present always nevertheless, serves to counter the dangers of 'inefficiency' both on the individual and imperial level. The South African War had humiliatingly laid bare the inherent weakness in the imperial war machine. If the British Empire was not to go the way of the Roman one, Lord Rosebery argued, the Empire needed "an imperial race - a race vigorous 
RAJAMÄE

and industrious and intrepid" (quoted in Reynolds 1996: 69), no "wishy-washy slackers without any go or patriotism in them" (thus General Baden-Powell, quoted ibid.). Comfortable suburban domesticity, embodied in the book by Alice, in such light would be, and is in the book, viewed with abhorrence, as waste of talent. To shake himself loose of Alice's clinging shadow and reassert his dented self-image as an intrepid, imperial adventurer whose field of operation is the whole world, Haystoun needs an impetus. This is provided by his defeat in the local elections which highlights as nothing else in the book the retreat of aristocratic power.

Haystoun agrees, half-heartedly as it is and to oblige a friend, to stand as a parliamentary candidate for the Conservative Party on his own turf, his constituency, where he is known as a model landlord. He enters the contest with age-old aristocratic notions of modesty and fair play which hinder his chances as they are countered by the brashness of the modern type of politician. $\mathrm{Mr}$ Stocks, his radical rival is a caricature of the suburban middle class meritocrat, a man who has made a profession of being a politician. He has the over-elaborate manners of a gentleman not to the manner born, is nastily clever and loftily dismissive of both aristocratic dilettantes and their university education with all the bitterness of a self-taught, self-made man with a touch of a nonconformist fanatic. He hungers for ostentation, exudes pompous self-importance and, ostensibly a democrat, is secretly very keen on aristocratic pedigrees and property. Lewis does badly also because he has the aristocrat's hatred of the new kind of political canvassing which the successive parliamentary reforms had brought about. While Mr Stocks can mouth easy platitudes with the slick conviction of a professional, the modest amateur baulks at self-advertisement.

Though Buchan attributes Lewis's failure to his personal qualities, his case is actually illustrative of a much wider phenomenon current at the time. As Cannadine (1996) has shown, the lower house of Parliament had, until the 1880s, been virtually a landowners' club, the majority of the MPs being recruited from the landed establishment. The upper house, which could thwart any of their bills, was filled with hereditary peers, who also dominated every cabinet, filled the key positions in national and local administration and their younger brothers and sons occupied prestigious jobs in the judiciary, the army, the church, the law and the civil service. The ethos of these patrician professions was leisured and amateur, their influence being so entrenched and sanctioned by the still unquestioned reverence of the populace that they were answerable to no one but themselves. To govern had been the business of the aristocracy and the gentry since time immemorial, it was their job and they had ensured their political dominance by restricting the agenda of political discussion to issues 
which interested them, these being mostly finance, religion, administration and foreign affairs. To avoid revolution, they had made concessions to the forces of change but until the last quarter of the nineteenth century their agglomeration of territory and title, power and influence had been so formidable and secure that they had remained a truly supra-national governing class which had largely retained its aristocratic exclusiveness. But the winds of change were already sweeping through their ranks even before the Third Reform Act of 1884 which dramatically changed the structure of rural politics to their disadvantage. In some heavily industrialised shires local administration had already been invaded by men of non-landed background. Increasing patrician poverty, the result of agricultural depression, and the changed and much enlarged electorate had decreased the number of landowners standing for parliament. The Third Reform Act heralded a new political era where the traditional methods of territorial control no longer sufficed and where the patricians themselves felt increasingly beleaguered. The Act abolished many small boroughs which in 1867 had been retained to support the landed interest and for the first time gave a fair share of seats to metropolitan, urban and industrial areas. The rearrangement of constituency boundaries created many new county constituencies which were wholly urbanized or suburbanized and reduced significantly the number of traditional rural seats where the aristocracy and gentry might still hope to feel at their ease. But worst of all, the Act dramatically extended the county franchise by giving the vote to the rural labourers. The situation for the local landed interest was further exacerbated by the Liberal reforms of the 1890s and 1900s which fundamentally changed the composition of the local magistracy and the Tory reform of local government which robbed the local magnates and gentry of most of their administrative functions. In more industrialized regions this brought along a virtual rural revolution, bringing democracy to the countryside. In more rural areas, where the old ways still persisted, the composition of the county councils nevertheless moved towards the greater inclusion of the middle classes. The changed nature of local government, more bureaucratic and professionalized, soon made the old style of amateur patrician government look increasingly anachronistic. It also changed the nature and working of county elections. In Cannadine's words:

They removed rural politics from the direct and confident control of the landed interest, and made necessary a wholly new style of political management. The demise of the old two-member constituencies meant that the traditional pattern of gentry-arranged compromise between conservative and radical candidates was no longer possible. The massive extension of the electorate meant that old methods of control (and intimidation) would no longer work. The need 
to canvass more widely and to organize more thoroughly, combined with the intrusion of party agents from London, meant that politics became more professional. And the growth in the number of contested elections, the increased influx of non-landed and carpet-bagger candidates, and the greater stress on national issues eroded the local and intimate nature of county politics, which had been the essential precondition for patrician dominance. (1996: 142)

For the landed interest the consequences of the Third Reform Act were not uniformly disastrous, for the great estates in Britain did not disappear overnight and if the landowners were willing to exert themselves, they could still play the most influential role in local politics. In many Scottish counties particularly the feeling of exclusiveness was retained, the landed proprietors and 'county families' still forming a class apart, way above the middle and working classes, but even there the middle-class professionals were becoming increasingly dominant in all local affairs. Nursing a constituency over a long period of time was now a costly and time-consuming business, especially in rural areas where constituencies were large and sprawling. A few speeches in the town hall would no longer suffice, for the candidate had to reach out to every enfranchised labourer in every village. Comfortable evenings at home spent with friends and houseguests had to give way to meetings and political gatherings in halls and schoolrooms, social activities of all sorts and a lot of travelling by motor car to reach distant locations. Many patricians found playing to the crowd demeaning and refused to stand, which further undermined their influence, for the county constituencies were then forced to turn to non-gentry, non-resident candidates. This resulted in the influx of middle-class outsiders into rural areas which had traditionally been the preserve of local aristocracy and resident gentry. This take-over of the rural seats by the moneyed interest and the demise of ancient political families at the hands of radical, nonconformist, petty bourgeois outsiders were much commented upon at the time, and even more so after the general election of 1906 which wiped out a whole cohort of patrician politicians. The final demise of the landed territorial control occurred with the Fourth Reform Act in 1918 which removed the last vestiges of the old system. In some Scottish constituencies the old families remained influential even after the First World War but their influence dwindled with the number of acres they were forced to sell to make ends meet. Effectively, though, in the 1920s and 30 s the landowners in most rural constituencies became marginalized, their places having been taken over by professional men with no local links in the community. (Ibid. 14-15, 148-153)

This is exactly what happens to Haystoun. Unable, because of his education and breeding to pander to the tastes of his audience of whose preferences he has 
no clear idea, though they are his own tenants, he loses out to Mr Stocks and has to look for meaningful employment elsewhere. Similarly, he has to hand over his lover to the middle-class upstart. Here, too, the middle class mores have made his special kind of refinement redundant, Alice, after her initial fascination with aristocratic nonchalance, coming to prefer the middle-class solidity of Mr Stocks. Luckily for Haystoun, the Russians are again stirring up trouble in Kashmir and he can go on his travels again.

Wratislaw, his mentor who recommends him for the mission, delineates a portrait of Haystoun for the benefit of his employers, and us, which is highly complimentary when applied to aristocrats like Haystoun whose upbringing had been steeped in chivalry and who consequently found their contemporary society not very amenable. These Late-Victorian and Edwardian young men were habitually described as having been born out of their time, in the sense of their being too chivalrous for the pragmatic modern age, where the qualities they had developed in themselves were useless or misplaced and their possible field of action severely curtailed by civilization which, by having invaded almost all the corners of the earth, left no scope for feats of daring and adventure. (Cannadine 1996: 382-383) They would have made either great Crusaders, Elizabethan explorers or, in the case of Scotland, noble embracers of lost causes, be it James V's at Flodden, the campaigns of Montrose or the Jacobite rebellions. These men need a new definition of success for modern times, now that their special qualities lay them open to misapplied charges of cowardice and inefficieny, sometimes self-applied, as is the case with Haystoun.

When it comes to sending Haystoun on his mission, Wratislaw expounds to him a doctrine of success which is the Victorian reworking of Castiglione's sprezzatura, now called competence. They both agree that competence is the highest happiness in life. It is important to note that competence does not equate with success, and this applies to all Buchan's heroes who wrestle with the same problem, no matter what ages they operate in. The distinction is vital and refutes two misunderstandings about his protagonists which frequently occur when it is overlooked. The first is that his upper-class heroes with brilliant careers are careerists, being so effortlessly successful, and the second that, as they usually turn down a prospect of material success, they have somehow chosen failure. In no later book is the difference between success and competence so explicitly analysed as in The Half-Hearted, so it merits a closer look.

And what do we mean by competence? [Wratislaw asks.] Not success! God knows it is something very different from success! Any fool may be successful, 
RAJAMÄE

if the gods wish to hurt him. Competence means that splendid joy in your own powers and the approval of your own heart, which great men feel always and lesser men now and again at favoured intervals. ( $\mathrm{HH} 150$ )

For Castiglione (1994: 380) sprezzatura was the highest form of competence in any field of action, achieved effortlessly by great men in whom it is a form of inborn grace and to be aspired to by lesser men, who should take their cue from their superiors and try to imitate them until, after hard practice, they have attained a verisimilitude of grace, which also signifies their moral improvement. To this the Victorians added Carlyle's Gospel of Work, expounded in his seminal On Heroes, the Hero-Worship and the Heroic in History and Past and Present, which was designed to banish religious doubt by advocating strenuous action, doing one's duty in the name of a higher cause, which would restore meaning to human existence. Following Goethe'e dictum 'Know thy work and do it!', Carlyle conceived of work as a modern form of chivalry, Chivalry of Work replacing the old Chivalry of Slaughter. To work was to join the celestial brotherhood of fighters, a pantheon of heroes who have fought honourably in the battlefields of life. All true work is religious by nature and to work is to worship, to go through a purifying fire which awakens the soul to a new life:

Blessed is he who has found his work; let him ask no other blessedness. He has a work, a life-purpose; he has found it and will follow it. /.../ Labour is Life: from the inmost heart of the Worker rises his god-given Force, the sacred celestial Life-essence breathed into him by Almighty God; from his inmost heart awakens him to all nobleness - to all knowledge, 'self-knowledge' and much else, as soon as Work fitly begins. /... / 'Doubt, of whatever kind, can be ended by Action alone.' (Carlyle 1961b.: 230-231)

Wratislaw echoes this when he says:

There are a certain number of things in the world to be done, and we have got to do them. We may fail - it doesn't in the least matter. We may get killed in the attempt - it matters still less. The things may not altogether be worth doing it is of very little importance. It is ourselves we have got to judge by. If we are playing our part well, and know it, then we can thank God and go on. That is what I call happiness. [...] And how are you to get happiness? Not by thinking about it. The greatest things of the world have all been done by men who didn't stop to reflect on them. If a man comes to a halt and analyses his motives and distrusts the value of the thing he strives for, then the odds are that his halt is final. You strive to strive and not to attain. (HH 150) 
It was the Romantics who had first posited the value of striving for striving's own sake. The Victorians, after Carlyle, strove towards the Ideal, a goal of unselfish action which he had also called Duty and the discovery and pursuit of which would win for them 'Spiritual Enfranchisement' for the vital energies of life which doubt and indecision had denied them. The Ideal, being abstract, could take on any number of meanings or remain altogether ill-defined. In the latter case striving for it frequently became an end in itself, a form of more passionate living, the inner eye of the pursuer focusing not so much on the vague or abstract ideal, as on one's pursuit of it. Victorian literature is full of passionate strivers with vaguely defined lofty aims, the most famous of them probably being Tennyson's Ulysses with his immortal, and highly influential, injunction "To strive, to seek, to find, and not to yield." (Houghton 1985: 253, 291-297)

With general striving goes forgetfulness of the self. Wratislaw again:

A man must have that direct practical virtue which forgets itself and sees only its work. Parsons will tell you that all virtue is self-sacrifice, and they are right, though not in the way they mean. It may all seem to you a tissue of contradictions. You must not pitch on too fanciful a goal, not, on the other hand, must you think on yourself. And it is a contradiction which only resolves itself in practice. ( $\mathrm{HH} 151)$

This is sprezzatura interpreted as recklessness (an English tradition going back to Elizabethan times), meaning a competence so perfect that one need no longer concentrate on what one is doing and can perform one's actions with complete abandon. Such forgetfulness of the self is the closest equivalent to inborn grace and was the supreme goal of Castiglione's courtier. It can also be the supreme goal of an empire-builder.

Haystoun achieves this by taking himself to the farthest corner of the Empire. When preparing himself for his last stand in a hitherto unknown pass about to be flooded by Russian troops, his doubts are banished, for he has found his true work. The half-hearted becomes the great-hearted, a true crusader in a foreign land (for he is well over the frontier line, in the no-man's land of the unexplored hills), a dreamer entering the distant Happy Country and yet the heroic man of action who at last would know the salt and iron of life. Standing at this farthest outpost of Empire, its sole guardian, an exile and wanderer, whose bones would never be found and whose glory would never be sung, a nameless sacrifice for the great common good, he can rejoice that he is about to join the brotherhood of warriors, kinsmen in one glorious enterprise which is the ultimate meaning of his quest. When the moment comes, he throws himself 
into the fight with reckless abandon, his self quite annihilated in this final surge of energy as he picks off his men one by one and then plunges into their midst, fighting like a maniac until trampled underfoot. He had humbly prayed to be allowed at least a good beginning or a gallant failure, but his is the ultimate victory, for his message reaches the south and as dawn breaks over his mangled body, the enemy knows himself to be beaten. But Haystoun's victory is also an intensely personal one, his selfless sacrifice being the highest proof of supreme competence.

Haystoun is an early manifestation of Buchan's 'iron dreamers', a type then very common and lauded as the quintessential empire-builder. Lonely, misunderstood, underrated and overlooked, they are sustained by their dream alone which sometimes culminates in their solitary imperial endeavour, sometimes in fulfilling a more personal goal. The type is perfectly rendered in an early short story 'Fountainblue' (1902) which traces the history of a solitary, alienated individual who finds his work and fulfilment at an imperial outpost. A Romantic Byronic hero in the making, he is drawn to wild nature and rugged landscapes. An aristocrat by birth but forced to earn his own living by working as a middle class entrepreneur, he lacks the social polish expected of his class, leading to the general misapprehension of his motives and character. Losing his loved one to a rival of superficial polish but no substance, he gives up a high government post and buries himself in darkest Africa, there carving out, unasked and unassisted, a whole new country for the Empire. To many this seems a folly and failure, a rich and powerful man throwing away a brilliant career for a whim of a girl but he has chosen true competence over false success. By going on his solitary imperial quest, he had not only proven his manliness to those who had not quite seen the right kind of sportsmanship in his makeup but reaffirmed his true gentility which had become tarnished from contact with the middle classes. Moreover, his is the only true version of gentility for the modern times, for the aristocracy has compromised itself by too close an alliance with new money. Characteristically, his true stature is only realized by a fellow empire-builder who likewise perishes on an imperial mission into unknown territory.

Buchan's 'iron dreamers' who stand above the vulgar crowd and tend to 'think in aeons and cosmic cycles' (CSS/II 53) radiate the mystique of omniscient manliness which, as J. Rutherford has shown (1997: 12), was a widespread literary response to the era of insecurity between 1870 and the First World War when the imperial mythology of heroic endeavour posited a hero with the famous stiff upper lip who transcended the insecurities and vicissitudes of modern masculinity to assume a cosmic dimension. Nothing he 
encountered was beyond his knowledge, his mastery over his environment was complete; whatever odds were stacked against him, his boundless confidence in his own powers carried all before him.

These 'men of destiny', like Francis Carey in Buchan's A Lodge in the Wilderness (1906), would effortlessly straddle continents and lord it over savages from their carefully placed hill stations. Imperial paternalism offered a comforting solution to the erosion of deference at home and scope of action which in industrial and increasingly more democratic Britain was becoming curtailed. If mere administration seemed too restrictive, the alternative role model was the pioneer. One of Carey's houseguests at Musuru, his fabulous hill station in equatorial Africa, Edward Considine, an explorer, famous biggame hunter and a pioneer himself, describes the attractions of that choice. If benevolent millionaires like Carey see their role in trusteeship, putting their material resources to a good use in civilizing the natives, pioneers have turned their backs on bourgeois materialism. Not caring for material rewards, they are dreamers whose work is "spiritual and unworldly":

We are the advance-guard, always pushing a little farther on and making the road easier for those who come after us, the serious solid fellows who make laws and create industries, and generally reap where we have sown. You cannot measure the work of a pioneer by the scale of a bagman. We keep the fire burning, though we go out ourselves. Our failure is our success. We don't found colonies and build cities, but unless we had gone before no one would have come after. (LW 103)

David Cannadine has perceptively discussed the phenomenon of patrician globe-trotting in the context of the social and cultural disintegration of the county society in the forty-odd years before the Great War. As the plutocrats and middle classes invaded the shires, the resentful and embattled older elite took to travelling as never before. Always a travelling class, the aristocracy sought out new playgrounds in ever more and more remote quarters of the globe in their effort to put as much distance between themselves and the inferior social groups beneath as was geographically possible. They preferred secluded nooks and corners of the already depressingly well-explored globe to find societies that were uncontaminated by modern ideas that had undermined their position at home:

Whereas in the eighteenth century the British aristocracy had despised the despotic politics and squalid conditions of so much of abroad, some of them now saw in its remote, unspoilt recesses their last best hope - where towns and 
RAJAMÄE

industry were non-existent, where hierarchy and paternalism prevailed, where the ancient values of chivalry and honour were still preserved. (1996: 382)

The combination of romance, chivalry and alienation experienced at home could give feats of exploration a quest-like intensity not unlike that of knighterrantry. The allure of distant places could be conveniently combined with diplomatic service where scions of great British families could talk as equals with native princes and nomad chiefs above the heads of lowly traders and middle-class politicians. (Ibid. 370-383)

Buchan's most famous globetrotting aristocrat is surely Sandy Arbuthnot, $16^{\text {th }}$ Baron Clanroyden whose overlapping careers in diplomacy and espionage allow generous doses of patrician globe-trotting. M. Fitzherbert, the biographer of Aubrey Herbert, Sandy's protopype in the early stages, has captured the mood of the period perfectly:

These sons and grandsons of the men who built the Empire were themselves neither builders nor destroyers. They were marked neither by the purpose and energy of their predecessors nor by the guilt and hesitation of their successors. Their inheritance was an ease around the world, and an infinite self-confidence. Following their knightly imaginations, wandering across the face of the earth, they had no axe to grind. Theirs was, briefly, an age of chivalry, soon to be laid at rest in the trenches of the Great War. (1984: 2-3)

Indeed, after the war, to refer to Cannadine again, the embattled territorial elite gradually ousted by new money from domains and spheres where they had felt secure and self-confident, had responded by turning their backs to the social system that had begun to break down and took themselves off to distant climes. The more they travelled, the less time they spent on their estates, thus further undermining their ancient role as resident and dutiful landowners and contributing to the irrevocable decay and disintegration of both the London society and their county communities which in turn added to their own frustration. Going on quests of knight-errantry to societies seemingly more amenable than their own to find refuge from the encroachments of modernity contributed to the patricians' feeling of restless- and rootlessness. What was worse, better means of transport and the growing tourist trade were opening up the formerly unreachable places to the common man and deprived even travel of a sense of exclusiveness. What in the pre-war years had been the privilege and pleasure of the few, by the after-war years had lost its glamour. Knight-errantry did not long survive the war, its great pre-war practitioners being either dead or disillusioned. (1996: 342-343, 383) 
This is precisely Sandy's plight. Having been forced to settle down in his native Scotland after the war due to family circumstances, he is restless and bored. To the uninitiated like his newly rich and middle-class friend Richard Hannay, Sandy's ancestral estate might look like earthly paradise but the owner is despondent. Partly this has to do with the world having grown too small and blasé for exotic adventure. It is characteristic of the times that when he is given his own adventure in The Courts of the Morning (1929), the location is shifted to South America which was then the least explored of continents, its forbidding terrain having attracted only the most determined patrician travellers. But even this is not distant enough for his chivalric quest, necessitating on Buchan's part the creation of fictional Olifa with what appear to be the remnants of an aristocratic territorial elite as yet unpolluted by money with the help of which to overthrow the international money-making concern that has taken over the country. Partly the reason is closer to home.

The flower of British aristocratic youth is traditionally taken to have perished in the fields of Flanders. But those who survived sometimes envied the dead, for all the negative trends intensified in the interwar years and contributed to patrician bitterness. Despite their huge sacrifice in the field, after the war they had to preside over the complete dismantling of their world. Feudalism was dead and most patricians, both young and old "contemplated the future with gloom and despondency that sometimes bordered on alarm" (Cannadine 1996: 85). Some developed an acute sense of uselessness and shame for their unearned privileges but their position and breeding made the choice of possible occupations a limited one. Thus we see Sandy complaining to Hannay that he lacks a proper job and the self-respect that goes with it. His trouble is compounded by the disintegration of the traditional political elite and the invasion of middle-class career politicians which we observed worried already Lewis Haystoun in The Half-Hearted. Things have only got worse and Sandy cannot contain his disgust when he contemplates the political scene. He yearns for the old disinterested service of the aristocratic kind which is no longer readily available. In the modern mercantile world his talents are redundant and he no longer feels that he fits in. Born "out of due season, and mighty discontented with his lot" (CM 9), he nostalgically recalls the old days when he and his friends had "a rather nice little Round Table" which is "all broken up now and the wood turned into cigar-boxes for wedding presents" and he alone is "the old buccaneer marooned on a rock, watching his ancient companions passing in ocean liners" (CM 10-11).

If Olifa's custom-made climes and terrains can still provide an almost credible locus for all sorts of dream campaigns and battles for a latter-day 
RAJAMÄE

knight who in the end receives the highest accolade by being offered the title of king, The Island of Sheep (1936) has to admit the inevitable erosion of the chivalric code even when it is applied in a determinedly paternalistic, distant, and fictional, setting - the Faroesque Norland islands. Sandy has chosen this setting for the show-down between himself and a fellow aristocratic villain and has visualized it as a classic feudal encounter of loyal retainers rallying to protect their lord and master, his native Norlander friend who needs his help. What he discovers upon arrival is that modernity has invaded even this distant outpost of feudalism. The retainers have left for better job opportunities on the mainland and his own carefully composed single combat with his adversary is ruined by his host's lack of any notion of chivalry.

Buchan's heroes tend to find a spell in the wilderness spiritually cleansing. When confused or troubled, they head for wild landscapes in order to regain spiritual balance. In Buchan's last book, Sick Heart River (1941), the protagonist Edward Leithen, mortally sick and disillusioned with his career as a lawyer, chooses for his spiritual rebirth the most distant and least frequented of aristocratic destinations - the Canadian Arctic. He hopes to expire in the majestic lifelessness of the icy wastes but finds himself instead called upon to strike a blow for life. As war breaks out in Europe, he, the veteran of the Great War, fights his own battle to save an ailing tribe of half-caste Indians from extinction. In doing so, he regains both his faith and aristocratic mission. Giving up his own life in the selfless service of others validates his quest and is rewarded by the beatific vision. All human striving and endeavour is ultimately part of God's eternal plan and no effort is ever wasted, for no matter how big or small, acts of nobility and kindness are always manifestations of divine love.

\author{
Pilvi Rajamäe \\ pilvi.rajamae@ut.ee \\ TÜ maailma keelte ja kultuuride kolledž \\ Anglistika osakond \\ Lossi 3 \\ 51003 Tartu \\ EESTI / ESTONIA
}


The Call of the Wild: John Buchan's Heroes and the Decline of British Aristocracy

\section{References}

Buchan, J. The Complete Short Stories. Vol. II. A. Lownie (ed.) 1997. London: Thistle Publishing.

Buchan, J. The Courts of the Morning. (1929) 1993. Edinburgh: B \& W Publishing.

Buchan, J. The Half-Hearted (1900) 2001. London: House of Stratus.

Buchan, J. The Island of Sheep (1936) 1995. Ware: Wordsworth.

Buchan, J. John Burnet of Barns (1898) 1994. Edinburgh: B and W Publishing.

Buchan, J. A Lodge in the Wilderness (1906) 1916. London: Thomas Nelson \& Sons, Ltd.

Buchan, J. A Lost Lady of Old Years (1988) 1995. Edinburgh: B and W Publishing

Buchan, J. Sick Heart River. (1941) 1994. Oxford: Oxford University Press.

Buchan, J. Sir Quixote of the Moors (1895) n.d. London: Robert Hayes, Ltd.

Cannadine, D. (1990) 1996. The Decline and Fall of the British Aristocracy. London: Papermac.

Carlyle, T. 1961a. On Heroes, Hero-Worship, and the Heroic in History. In C. F. Harrold, W. D. Templeman (eds.) English Prose of the Victorian Era. New York: Oxford University Press.

Carlyle, T. 1961b. Past and Present. In C. F. Harrold, W. D. Templeman (eds.) English Prose of the Victorian Era. New York: Oxford University Press.

Castiglione, B. 1994. The Book of the Courtier. T. Hoby (trans.) V. Cox (ed.) London: Everyman.

Fitzherbert, M. (1983) 1984. The Man Who Was Greenmantle. London: John Murray.

Houghton, W. E. (1957) 1985. The Victorian Frame of Mind, 1830-1870. New Haven and London: Yale University Press.

Reynolds, D. (1991) 1996. Britannia Overruled. British Policy and World Power in the $20^{\text {th }}$ Century. London and New York: Longman.

Rutherford, J. 1997. Forever England. Reflections on Masculinity and Empire. London: Lawrence and Wishart. 